\title{
The fate of orally available antimicrobials
}

\author{
B Catry ${ }^{1 *}$, D Persoons ${ }^{2}$, J Dewulf ${ }^{2}$ \\ From International Conference on Prevention \& Infection Control (ICPIC 2011) \\ Geneva, Switzerland. 29 June - 2 July 2011
}

\section{Introduction / objectives}

Changing an antimicrobial treatment regimen has shown to influence the occurrence of antimicrobial resistance, with regimen consisting of the dose, the treatment interval, the duration of therapy, and the route of administration of the drug. For concentration dependent antimicrobials there is substantial evidence to encourage the use of a high dose, with regular treatment interval and short course to minimise the risk for the selection of resistant mutants. However, in contrast with these first three aspects of the antimicrobial treatment regimen, little attention is currently paid to the influence of route of administration for the probability of selection and spread of resistant strains.

\section{Methods}

By comparing data from different animal species, the purpose is to explore the different routes of administration with regard to the stimulation of antimicrobial resistance.

\section{Results}

A historical review on the emergence of resistance to beta-lactamas and tetracycline in Staphylococcus aureus and Escherichia coli in different animal species and humans will be provided. Data on commonly used treatment regimens for humans and animal will be compared and the potential impact on selection, co-selection and spread of resistance will be discussed escriptively. Special attention will be given to the difference in resistance development between topical, oral, and parenteral administration of antimicrobial agents.

\section{Conclusion}

Attention to the route of administration might be an underestimated approach to mitigate the risk of

'Healthcare associated infections (NSIH), Scientific Institute of Public Health, Brussels, Belgium

Full list of author information is available at the end of the article selection for pathogens resistant to antimicrobials in both human and veterinary medicine.

\section{Disclosure of interest}

None declared.

\section{Author details}

'Healthcare associated infections (NSIH), Scientific Institute of Public Health, Brussels, Belgium. ${ }^{2}$ Ghent University, Merelbeke, Belgium.

Published: 29 June 2011

doi:10.1186/1753-6561-5-S6-P44

Cite this article as: Catry et al:: The fate of orally available

antimicrobials. BMC Proceedings 2011 5(Suppl 6):P44.
Submit your next manuscript to BioMed Central and take full advantage of:

- Convenient online submission

- Thorough peer review

- No space constraints or color figure charges

- Immediate publication on acceptance

- Inclusion in PubMed, CAS, Scopus and Google Scholar

- Research which is freely available for redistribution

\section{() Biomed Central}

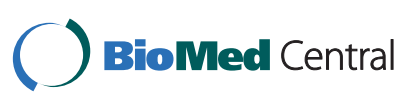

(c) 2011 Catr et al; licensee BioMed Central Ltd. This is an open access article distributed under the terms of the Creative Commons Attribution License (http://creativecommons.org/licenses/by/2.0), which permits unrestricted use, distribution, and reproduction in any medium, provided the original work is properly cited. 